\title{
The Contemporary Observations of Paradiplomacy: The Case of Sabah-Australia Connections
}

\section{Rizal Zamani Idris, Rafiq Idris, Azizan Morshidi}

To Link this Article: http://dx.doi.org/10.6007/IJARBSS/v11-i2/9198

DOI:10.6007/IJARBSS/v11-i2/9198

Received: 14 December 2020, Revised: 15 January 2021, Accepted: 31 January 2021

Published Online: 25 February 2021

In-Text Citation: (Idris et al., 2021)

To Cite this Article: Idris, R. Z., Idris, R., \& Morshidi, A. (2021). The Contemporary Observations of Paradiplomacy: The Case of Sabah-Australia Connections. International Journal of Academic Research in Business and Social Sciences, 11(2), 1227-1233.

\section{Copyright: ( 2021 The Author(s)}

Published by Human Resource Management Academic Research Society (www.hrmars.com)

This article is published under the Creative Commons Attribution (CC BY 4.0) license. Anyone may reproduce, distribute, translate and create derivative works of this article (for both commercial and non-commercial purposes), subject to full attribution to the original publication and authors. The full terms of this license may be seen at: http://creativecommons.org/licences/by/4.0/legalcode

Vol. 11, No. 2, 2021, Pg. 1227 - 1233

Full Terms \& Conditions of access and use can be found at http://hrmars.com/index.php/pages/detail/publication-ethics 


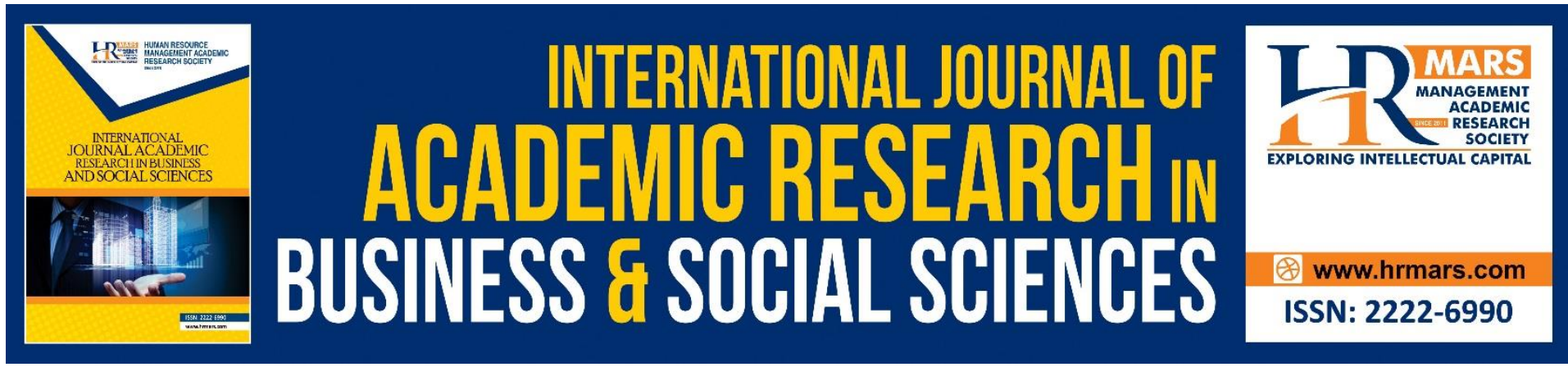

\title{
The Contemporary Observations of Paradiplomacy: The Case of Sabah-Australia Connections
}

\author{
Rizal Zamani Idris, Rafiq Idris, Azizan Morshidi \\ Faculty of Social Sciences and Humanities, Universiti Malaysia Sabah, 88999 Kota Kinabalu, \\ Sabah, Malaysia
}

\begin{abstract}
Diplomacy has always been seen as a state-centric matter that views state as the only actor in international relations. Nevertheless, since the end of the Cold War, this belief has been challenged with the growing role of multinational as well as sub-state entities in international political arena. Malaysia-Australia relations have been shaped with numerous issues and challenges. Despite their bumpy political ties in the past (especially during the prime ministership of $\mathrm{dr}$. Mahathir Mohamad) other spheres of the relationship remained unaffected. As such, a case study is conducted by looking at Sabah-Australia relations in terms of paradiplomatic practices. This research is qualitative in nature. Initial findings indicate that historical imperatives as well as trading interactions are two forms paradiplomatic practice that has contributed to strengthening of Malaysia-Australia relations.
\end{abstract}

Keywords: Paradiplomacy, Sabah, Australia, Historical Imperatives, Trading Interactions

\section{Introduction}

The importance of bilateralism is evident in the study of international relations. Since the end of World War I and the inception of International Relations discipline in 1919, emphasis has been given by scholars and world leaders on the efforts on how to avoid war from recurring. Ever since, numerous theories have been developed and promoted to strengthen ties between countries.

Diplomacy has always been seen as a state-centric matter that sees state as the only actor in international relations. Nevertheless, since the end of the Cold War, this belief has been challenged. The forces of globalization has made interactions between nations to be multi-faceted. Paradiplomacy is referred to as "...the involvement of the constituent units (regions) of (multi)national states in international affairs" (Kuznetsov, 2015).

Liu and Song define (2020) paradiplomacy as "...the conduct of external engagements (across socioeconomic, security, and energy fields, for example) by subnational/provincial governments in both federal and unitary systems." In short, paradiplomacy can be understood as the 'parallel diplomacy' that is practiced by sub-state or sub-national governments.

It has to be noted that the bilateral ties between Malaysia and Australia have been tested with various challenges in the past that had almost jeopardized their diplomatic 
relations (Camilleri, 2001; Shamsul, 1996). This was evident especially during the administration of Malaysia's fourth Prime Minister, Dr. Mahathir Mohamad. Interestingly, despite the bumpy ties of their troubled governmental relationship, other spheres of the relationship remained in-tact and unaffected (Idris, 2018). As a matter of fact, the ties between these two countries continue to grow that have benefitted both parties.

As such, it is argued that the role of 'paradiplomacy' in the case of Sabah and Australia has in one way or another not only strengthened the bonds of interactions between the two entities but also indirectly promoted better understanding and cooperation between Malaysia and Australia. As such, this paper will briefly discuss the initial findings of paradiplomatic practices between these two entities.

\section{Past Studies}

It is interesting to note that there has been an abundant number of studies that have been conducted pertaining to the area of paradiplomacy. However, it is also important emphasize that there is a dearth in terms of literature, especially in the aspect of paradiplomacy of nonwestern states (Liu \& Song, 2020).

The latest available work on paradiplomacy published in reputable journal entitled Chinese Paradiplomacy : A Theoretical Review, written by Liu \& Song. They argue that the existing analytical framework of paradiplomatic studies confined itself to the limited ascpect of the phenomenon only and are mostly on Western world case studies. Hence their discussion expands the geographical scope of non-Western paradiplomacy. Kuznetsov (2015) examines the theoretical dimension of paradiplomacy and the roe of sub-national governments in international politics.

Other important works include Aguirre (1999); Lejeune (1990); Putnam (1988); Leach, Walker \& Levy (1973); Atkey (1970).

\section{Initial Findings}

\section{i. Historical Imperatives}

In terms of security, during World War II, Australian troops were closely involved in defending Malaya (1941-1942) and the Borneo states of Sabah and Sarawak (1945). They had also provided a temporary interim military government in Sabah and Sarawak right away after the Japanese forces had surrendered to the Allied Forces during World War II (Williams, 1992: pp. $2 \& 8$ ). That was not all, with the request made by the Malaysian government, Australia dispatched its troops in 1965, joining the British, Malaysian and other Commonwealth countries to protect Malaysia from the threats posed by Indonesia during the Konfrontasi (Cochrane, 2001; p. 203; Idris et. al 2010).

These experiences have contributed to the strengthening of engagements between these two entities (Sabah and Australia). For example, The Sandakan Memorial Day is held annually (every $15^{\text {th }}$ August) to commemorate the sacrifices of the Australian prisoners of war (PoWs) in defending Sabah during the Second World War. This occasion draws hundreds of visitors both from the country and overseas every year to mourn the loss, honor the heroes and remember the history that was made. It is a continuous tradition to ensure history is remembered but not repeated.

In terms of education, many students from the state had benefitted from the Colombo Plan. The Colombo Plan was a clear manifestation of Australia's strong educational commitment and support to Malaysia and the region in general. As a result, many Australian- 
educated Sabahans were heavily represented in politics, economics, academia and other fields in the country.

\section{ii) Trade Interactions}

Malaysia and Australia are trading partners for many years and share common open economy (Idris, 2015, 2016; Idris \& Idris, 2013). Trading interactions between Sabah and Australia contribute greatly to the economic interests of both entities. As of 2019, Sabah recorded a trade surplus with Australia, despite having trade deficit for certain product categories such as Food (Sitc-0), Crude Materials (Sitc-2) (See Table 1 Below).

Table 1. Sabah- Australia Trade 2019 (Source : Department of Statistics Malaysia, 2020)

\begin{tabular}{|c|c|c|c|c|c|}
\hline \multicolumn{6}{|c|}{ SABAH-AUSTRALIA TRADE (2019) } \\
\hline \begin{tabular}{|l|l|} 
SITC & PRODUCT CATEGORIES \\
\end{tabular} & EXPORT TO AUSTRALIA (RM) & IMPORT FROM AUSTRALIA (RM) & TOTAL TRADE (RM) & TRADE BALANCE (RM) & TRADE BALANCE POSITION \\
\hline \begin{tabular}{|l|l|}
0 & FOOD \\
\end{tabular} & $90,891,996$ & $173,111,209$ & $264,003,205$ & $(82,219,213)$ & DEFICIT \\
\hline \begin{tabular}{|l|l|}
1 & BEVERAGES AND TOBACCO \\
\end{tabular} & & $6,839,280$ & $6,839,280$ & $(6,839,280)$ & DEFICIT \\
\hline 2 CRUDE MATERIALS, INEDIBLE & $7,409,296$ & $24,011,890$ & $31,421,186$ & $(16,602,594)$ & DEFICIT \\
\hline \begin{tabular}{|l|l}
3 & MINERAL FUELS, LUBRICANTS, ETC. \\
\end{tabular} & $4,382,590,471$ & 161,739 & $4,382,752,210$ & $4,382,428,732$ & SURPLUS \\
\hline \begin{tabular}{|l|l|}
4 & ANIMAL AND VEGETABLE OILS AND FATS \\
\end{tabular} & & 33,851 & 33,851 & $(33,851)$ & DEFICIT \\
\hline \begin{tabular}{|l|l|}
5 & CHEMICALS \\
\end{tabular} & $224,582,367$ & $10,777,169$ & $235,359,536$ & $213,805,198$ & SURPLUS \\
\hline \begin{tabular}{|l|l|}
6 & MANUFACTURED GOODS \\
\end{tabular} & $5,306,861$ & $3,374,213$ & $8,681,074$ & $1,932,648$ & SURPLUS \\
\hline 7 MACHINERY \& TRANSPORT EQUIPMENT & $11,846,913$ & $16,124,562$ & $27,971,475$ & $(4,277,649)$ & DEFICIT \\
\hline \begin{tabular}{|l|l|}
8 & MISCELLLANEOUS MANUFACTURED ARTICLES \\
\end{tabular} & $7,450,266$ & $5,490,599$ & $12,940,865$ & $1,959,667$ & SURPLUS \\
\hline \begin{tabular}{|l|l|l|}
9 & MISCELLANEOUS TRANSACTIONS AND COMMODITIES \\
\end{tabular} & 551,090 & $1,156,850$ & $1,707,940$ & $(605,760)$ & DEFICIT \\
\hline TOTAL & $4,730,629,260$ & $241,081,362$ & $4,971,710,622$ & $4,489,547,898$ & SURPLUS \\
\hline
\end{tabular}

Table 2. Sabah's Export To Australia At 2 Digit Code (Source : Department of Statistics Malaysia, 2020)

\begin{tabular}{|c|c|c|}
\hline SITC & PRODUCT CATEGORIES & EXPORT TO AUSTRALIA (RM) \\
\hline 03 & FISH (NOT MARINE MAMMALS), CRUSTACEANS, MOLLUSCS AND AQUATIC INVERTEBRATES, AND PREPARATIONS THEREOF & $66,138,432$ \\
\hline 04 & CEREALS AND CEREAL PREPARATIONS & 38,694 \\
\hline 08 & FEEDING STUFF FOR ANIMALS (NOT INCLUDING UNMILLED CEREALS) & $24,633,020$ \\
\hline 09 & MISCELLANEOUS EDIBLE PRODUCTS AND PREPARATIONS & 81,850 \\
\hline 23 & CRUDE RUBBER (INCLUDING SYNTHETIC AND RECLAIMED) & $1,055,600$ \\
\hline 24 & CORK AND WOOD & $6,255,963$ \\
\hline 26 & TEXTILE FIBRES (OTHER THAN WOOL TOPS AND OTHER COMBED WOOL) AND THEIR WASTES (NOT MANUFACTURED INTO YARN OR FABRIC) & 75,826 \\
\hline 27 & CRUDE FERTILIZERS, OTHER THAN THOSE OF DIVISION 56, AND CRUDE MINERALS (EXCLUDING COAL, PETROLEUM AND PRECIOUS STONES) & 11,263 \\
\hline 29 & CRUDE ANIMAL AND VEGETABLE MATERIALS, N.E.S. & 10,644 \\
\hline 33 & PETROLEUM, PETROLEUM PRODUCTS AND RELATED MATERIALS & $4,382,590,471$ \\
\hline 51 & ORGANIC CHEMICALS & 45,840 \\
\hline 52 & INORGANIC CHEMICALS & 23,577 \\
\hline 56 & FERTILIZERS (OTHER THAN THOSE OF GROUP 272) & $223,682,690$ \\
\hline 58 & PLASTICS IN NON-PRIMARY FORMS & 5,458 \\
\hline 59 & CHEMICAL MATERIALS AND PRODUCTS, N.E.S. & 824,802 \\
\hline 62 & RUBBER MANUFACTURES, N.E.S. & 64,297 \\
\hline 63 & CORK AND WOOD MANUFACTURES (EXCLUDING FURNITURE) & $2,407,843$ \\
\hline 65 & TEXTILE YARN, FABRICS, MADE-UP ARTICLES, N.E.S., AND RELATED PRODUCTS & 80,611 \\
\hline 67 & IRON AND STEEL & $1,904,737$ \\
\hline 69 & MANUFACTURES OF METALS, N.E.S. & 849,373 \\
\hline 71 & POWER-GENERATING MACHINERY AND EQUIPMENT & 145,076 \\
\hline 72 & MACHINERY SPECIALIZED FOR PARTICULAR INDUSTRIES & $9,208,752$ \\
\hline 73 & METALWORKING MACHINERY & 67,891 \\
\hline 74 & GENERAL INDUSTRIAL MACHINERY AND EQUIPMENT, N.E.S., AND MACHINE PARTS, N.E.S. & $1,571,114$ \\
\hline 75 & OFFICE MACHINES AND AUTOMATIC DATA-PROCESSING MACHINES & 20,286 \\
\hline 76 & TELECOMMUNICATIONS AND SOUND-RECORDING AND REPRODUCING APPARATUS AND EQUIPMENT & 22,256 \\
\hline 77 & ELECTRICAL MACHINERY, APPARATUS AND APPLIANCES, N.E.S., AND ELECTRICAL PARTS THEREOF (INCLUDING NONELECTRICAL COUNTERPAR & 796,068 \\
\hline 78 & ROAD VEHICLES (INCLUDING AIR-CUSHION VEHICLES) & 7,195 \\
\hline 79 & OTHER TRANSPORT EQUIPMENT & 8,275 \\
\hline 83 & TRAVEL GOODS, HANDBAGS AND SIMILAR CONTAINERS & 2,071 \\
\hline 84 & ARTICLES OF APPAREL AND CLOTHING ACCESSORIES & 2,927 \\
\hline 87 & PROFESSIONAL, SCIENTIFIC AND CONTROLLING INSTRUMENTS AND APPARATUS, N.E.S. & $7,074,170$ \\
\hline 89 & MISCELLANEOUS MANUFACTURED ARTICLES, N.E.S. & 371,098 \\
\hline 93 & SPECIAL TRANSACTIONS AND COMMODITIES NOT CLASSIFIED ACCORDING TO KIND & 551,090 \\
\hline & TOTAL EXPORT & $4,730,629,260$ \\
\hline
\end{tabular}


Based on the table above, Sabah's main export products to Australia include Petroleum (Sitc33), Fertilizers (Sitc-56), Fish, Crustaceans, Mollucs (Sitc-03), Feeding Stuff For Animals (Sitc08). It is clearly indicated that Sabah's comparative advantage in the mentioned products are indeed the highest products that Australia imported from Sabah in 2019.

Table 3. Sabah's Export To Australia At 2 Digit Code (Source : Department of Statistics Malaysia, 2020)

\begin{tabular}{|c|c|c|}
\hline SITC & PRODUCT CATEGORIES & IMPORT FROM AUSTRALIA (RM) \\
\hline 00 & LIVE ANIMALS OTHER THAN ANIMALS OF DIVISION 03 & $5,939,782$ \\
\hline 01 & MEAT AND MEAT PREPARATIONS & $38,663,390$ \\
\hline 02 & DAIRY PRODUCTS AND BIRDS' EGGS & $13,207,618$ \\
\hline 03 & FISH (NOT MARINE MAMMALS), CRUSTACEANS, MOLLUSCS AND AQUATIC INVERTEBRATES, AND PREPARATIONS THEREOF & $2,270,828$ \\
\hline 04 & CEREALS AND CEREAL PREPARATIONS & $87,064,581$ \\
\hline 05 & VEGETABLES AND FRUIT & $17,515,475$ \\
\hline 06 & SUGARS, SUGAR PREPARATIONS AND HONEY & 281,745 \\
\hline 07 & COFFEE, TEA, COCOA, SPICES, AND MANUFACTURES THEREOF & $5,452,460$ \\
\hline 08 & FEEDING STUFF FOR ANIMALS (NOT INCLUDING UNMILLED CEREALS) & 991,541 \\
\hline 09 & MISCELLANEOUS EDIBLE PRODUCTS AND PREPARATIONS & $1,723,789$ \\
\hline 11 & BEVERAGES & $6,839,280$ \\
\hline 22 & OIL-SEEDS AND OLEAGINOUS FRUITS & 5,575 \\
\hline 24 & CORK AND WOOD & 70,534 \\
\hline 26 & TEXTILE FIBRES (OTHER THAN WOOL TOPS AND OTHER COMBED WOOL) AND THEIR WASTES (NOT MANUFACTURED INTO YARN OR FABRIC) & 50,970 \\
\hline 27 & CRUDE FERTILIZERS, OTHER THAN THOSE OF DIVISION 56, AND CRUDE MINERALS (EXCLUDING COAL, PETROLEUM AND PRECIOUS STONES) & $18,445,275$ \\
\hline 28 & METALLIFEROUS ORES AND METAL SCRAP & $4,349,083$ \\
\hline 29 & CRUDE ANIMAL AND VEGETABLE MATERIALS, N.E.S. & $1,090,453$ \\
\hline 33 & PETROLEUM, PETROLEUM PRODUCTS AND RELATED MATERIALS & 161,739 \\
\hline 42 & FIXED VEGETABLE FATS AND OILS, CRUDE, REFINED OR FRACTIONATED & 33,851 \\
\hline 51 & ORGANIC CHEMICALS & 345,880 \\
\hline 52 & INORGANIC CHEMICALS & 2,625 \\
\hline 55 & ESSENTIAL OILS AND RESINOIDS AND PERFUME MATERIALS; TOILET, POLISHING AND CLEANING PREPARATIONS & 444,203 \\
\hline 56 & FERTILIZERS (OTHER THAN THOSE OF GROUP 272) & $1,128,882$ \\
\hline 57 & PLASTICS IN PRIMARY FORMS & $5,918,041$ \\
\hline 58 & PLASTICS IN NON-PRIMARY FORMS & 28,646 \\
\hline 59 & CHEMICAL MATERIALS AND PRODUCTS, N.E.S. & $2,908,892$ \\
\hline 61 & LEATHER, LEATHER MANUFACTURES, N.E.S., AND DRESSED FURSKINS & 4,129 \\
\hline 62 & RUBBER MANUFACTURES, N.E.S. & 669,465 \\
\hline 65 & TEXTILE YARN, FABRICS, MADE-UP ARTICLES, N.E.S., AND RELATED PRODUCTS & 159,876 \\
\hline 66 & NON-METALLIC MINERAL MANUFACTURES, N.E.S. & 182,222 \\
\hline 67 & IRON AND STEEL & 730,486 \\
\hline 68 & NON-FERROUS METALS & 4,439 \\
\hline 69 & MANUFACTURES OF METALS, N.E.S. & $1,623,596$ \\
\hline 71 & POWER-GENERATING MACHINERY AND EQUIPMENT & 887,013 \\
\hline 72 & MACHINERY SPECIALIZED FOR PARTICULAR INDUSTRIES & $6,690,967$ \\
\hline 73 & METALWORKING MACHINERY & 50,440 \\
\hline 74 & GENERAL INDUSTRIAL MACHINERY AND EQUIPMENT, N.E.S., AND MACHINE PARTS, N.E.S. & $2,013,154$ \\
\hline 55 & OFFICE MACHINES AND AUTOMATIC DATA-PROCESSING MACHINES & 47,003 \\
\hline 76 & TELECOMMUNICATIONS AND SOUND-RECORDING AND REPRODUCING APPARATUS AND EQUIPMENT & 366,828 \\
\hline $\mathbf{F}$ & ELECTRICAL MACHINERY, APPARATUS AND APPLIANCES, N.E.S., AND ELECTRICAL PARTS THEREOF (INCLUDING NONELECTRICAL & \\
\hline 77 & COUNTERPARTS, N.E.S., OF ELECTRICAL HOUSEHOLD-TYPE EQUIPMENT) & 560,974 \\
\hline 78 & ROAD VEHICLES (INCLUDING AIR-CUSHION VEHICLES) & $2,681,591$ \\
\hline 79 & OTHER TRANSPORT EQUIPMENT & $2,826,592$ \\
\hline 81 & PREFABRICATED BUILDINGS; SANITARY PLUMBING, HEATING AND LIGHTING FIXTURES AND FITIINGS, N.E.S. & 95,129 \\
\hline 82 & FURNITURE AND PARTS THEREOF; BEDDING, MATTRESSES, MATTRESS SUPPORTS, CUSHIONS AND SIMILAR STUFFED FURNISHINGS & 19,639 \\
\hline 83 & TRAVEL GOODS, HANDBAGS AND SIMILAR CONTAINERS & 14,608 \\
\hline 84 & ARTICLES OF APPAREL AND CLOTHING ACCESSORIES & 70,530 \\
\hline 85 & FOOTWEAR & 6,500 \\
\hline 87 & PROFESSIONAL, SCIENTIFIC AND CONTROLLING INSTRUMENTS AND APPARATUS, N.E.S. & $2,041,099$ \\
\hline 88 & PHOTOGRAPHIC APPARATUS, EQUIPMENT AND SUPPLIES AND OPTICAL GOODS, N.E.S.; WATCHES AND CLOCKS & 3,649 \\
\hline 89 & MISCELLANEOUS MANUFACTURED ARTICLES, N.E.S. & $3,239,445$ \\
\hline 93 & SPECIAL TRANSACTIONS AND COMMODITIES NOT CLASSIFIED ACCORDING TO KIND & $1,156,850$ \\
\hline
\end{tabular}

As shown in the table above, Sabah's main import products from Australia are Cereal \& Cereal Preparations (Sitc-04), Meat \& Meat Preparations (Sitc-01), Crude Fertilizers, (Sitc-27), Vegetables \& Fruits (Sitc-05) And Dairy Products (Sitc-02). In other words, Australia offered most of the dairy products that became Sabah's main imported products from Australia. 


\section{Conclusion}

Diplomacy has always been said to be a state-centric affair that views states as the dominant and only actor in international relations. However, this belief has been challenged since the end of the Cold War and the growing role of multinational as well as sub-state entities in international political arena.

As in the case of Sabah and Australia, both entities have enjoyed tremendous benefits that have eventually advanced the bilateral relations between Malaysia and Australia. As discussed in the paper, initial findings have shown that historical imperatives as well as trade interactions are two forms of paradiplomatic relationship that have taken place between them.

The continued historical legacy as well as trade interactions have indirectly strengthened the bonds of the peoples (Sabahans and Australians). These interactions are believed to bring about greater potentialities between the peoples to expand even further. The existing paradiplomatic practices could become the driving force for greater Sabah and MalaysiaAustralia relations.

\section{Acknowledgement}

The authors thank Universiti Malaysia Sabah (UMS) for valuable help in the research and publication process. This research was conducted within the larger project funding of UMS internal research grant SGA0120-2019.

\section{Corresponding Author}

Rizal Zamani Bin Idris (Ph.D)

Faculty of Social Sciences and Humanities, Universiti Malaysia Sabah

Universiti Malaysia Sabah, Jalan UMS, 88999 Kota Kinabalu, Sabah

Email: rizal@ums.edu.my

\section{References}

Aguirre, I. (1999). Making sense of paradiplomacy? An intertextual enquiry about a concept in search of a definition, Regional \& Federal Studies, 9(1), 185-209

Atkey, R. (1970). The role of the provinces in international affairs. International Journal, 26(1), 249-273.

Cochrane P. (2001). Australians at War. Sydney : ABC Books

Kuznetsov, A. S. (2015). Theory and Practice of Paradiplomacy Subnational Governments in International Affairs, New York:Routledge

Leach, R., Walker, D., \& Levy, T. (1973). Province-state transborder relations: A preliminary assessment. Canadian Public Administration, 16(3), 468-482.

Lejeune, Y. (1990). Belgium. In H. J. Michelmann \& P. Soldatos (Eds.), Federalism and international relations: The role of subnational units (pp. 142-175). Clarendon Press.

Liu, T., \& Song, Y. (2020) Chinese Paradiplomacy: A Theoretical Review, SAGE Open, 10(1),114

Putnam, R. (1988). Diplomacy And Domestic Politics: The Logic of Two-level Games. International Organizations, 42(3), 427-460

Idris, R., \& Idris, R. Z. (2013). Is Foreign Direct Investment (FDI) The Cause of Malaysia's Export? Australian Journal of Basic \& Applied Sciences, March, 194-197

Idris, R. (2015). Sabah in 1962 and 2011 : A Snapshot of Its Foreign Trade and Comparative Advantage. Asia Pacific Journal of Research, 1 (38), 192-199 
Idris, R. (2016). Trade Openness in Malaysia: Evidence from Trade with ASEAN and Australasian Countries. Scholars of Journal Economics, Business and Management, 3(12),669-679

Idris, R. Z., Bala B., Morshidi, A. (2013). Sabah (Malaysia) - Australia Relations: An Historical Observation. TAWARIKH : International Journal for Historical Studies, 5(2), 151-170

Idris, R. Z. (2018) Malaysia-Australia Relations (1981-2003): An Analysis From The English School Perspective, Ph.D Thesis, Universiti Malaysia Sabah, 2018 (Unpublished)

Williams B. (1992). Australia and Malaysia. Kuala Lumpur: Lai Publishing Pte. Ltd 